\title{
FLOOD PROFILES OF THE PITHLACHASCOTEE RIVER, WEST-CENTRAL FLORIDA
}

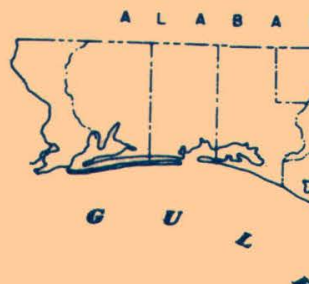

\section{U.S. GEOLOGICAL SURVEY}

Water-Resources Investigations 78-100

Prepared in cooperation with the SOUTHWEST FLORIDA WATER MANAGEMENT DISTRICT 
FLOOD PROFILES OF THE PITHLACHASCOTEE RIVER, WEST-CENTRAL FLORIDA

\section{Author(s)}

Turner, J. F., Jr., Murphy, W. R., Jr., and Reeter, C. V.

9. Performing Organization Name and Address

U.S. Geological Survey, Water Resources Division

325 John Knox Road, Suite F-240

Tallahassee, Florida 32303

12. Sponsoring Organization Name and Address

U.S. Geological Survey, Water Resources Division

325 John Knox Road, Suite F-240

Tallahassee, Florida 32303

13. Type of Report \& Period Covered

\section{Supplementary Notes}

Prepared in cooperation with the Southwest Florida Water Management District

\section{Abstracts}

Data defining the magnitude and frequency of flooding are provided for a non-tida 16-mile reach of the Pithlachascotee River. These data include areal flood-frequency relations and flood heights for the 2-, 2.33-, 5-, 10-, 25-, 50-, 100-, 200-, and 500year recurrence intervals. Flood profiles are provided for the 2.33-, 5-, 10-, 100-, and 500-year recurrence intervals.

Study results indicate that flood discharges in the study area are highly variabl and are one-third to one-half of regional estimates. Differences between study area and regional estimates are due to large quantities of flood-water drainage to the regional aquifer system in the upper basin, a large karst area of about 138 square miles. Graded roads and bridges located at three sites along the upper study reach will be inundated by various frequency floods.

Flood inundation maps can be prepared from flood data presented in this report.

\section{Key Words and Document Analysis. 17a. Descriptors}

*Flood plain zoning, *Flood plains, *Floods

\section{7b. Identifiers/Open-Ended Terms}

Pithlachascotee River, Hernando County, Pasco County

17c. COSATI Field/Group

19. Security Class (This Report)

UNCLASSIFIED

20. Security Class (This Page
21. No. of Pages 28

22. Price 
FLOOD PROFILES OF THE PITHLACHASCOTEE RIVER, WEST-CENTRAL FLORIDA

By J. F. Turner, Jr., W. R. Murphy, Jr., and C. V. Reeter

U.S. GEOLOGICAL SURVEY

Water-Resources Investigations 78-100

Prepared in cooperation with the

SOUTHWEST FLORIDA WATER MANAGEMENT DISTRICT 
UNITED STATES DEPARTMENT OF THE INTERIOR

CECIL D. ANDRUS, Secretary

GEOLOGICAL SURVEY

H. William Menard, Director

For additional information write to:

U.S. Geological Survey

325 John Knox Road, F-240

Ta1lahassee, Florida 32303 
Conversion factors $\ldots \ldots \ldots \ldots \ldots \ldots \ldots \ldots \ldots \ldots \ldots \ldots \ldots \ldots \ldots$ iv

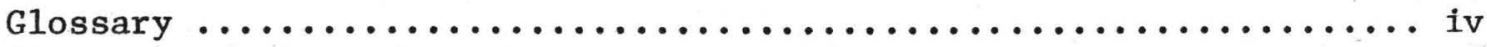

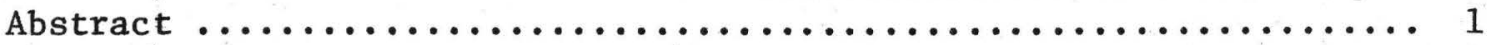

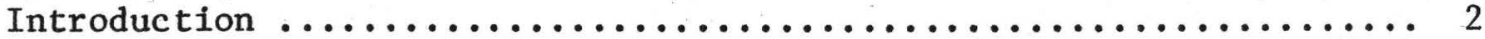

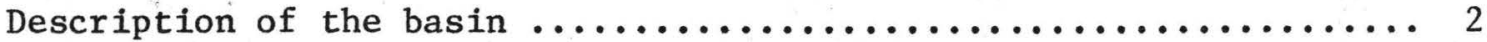

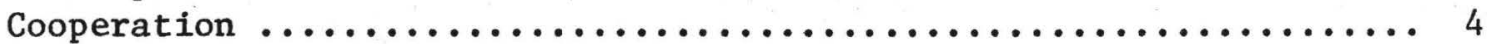

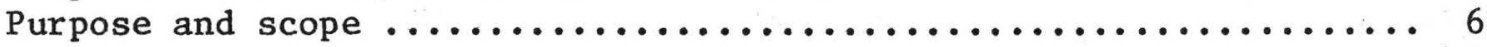

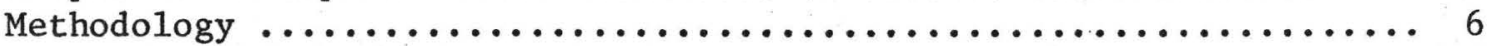

Areal flood-frequency relations $\ldots \ldots \ldots \ldots \ldots \ldots \ldots \ldots \ldots \ldots \ldots \ldots$

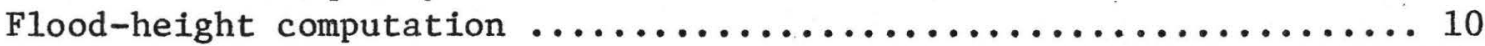

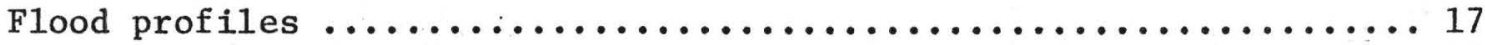

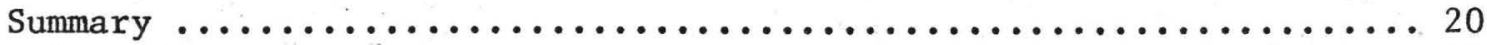

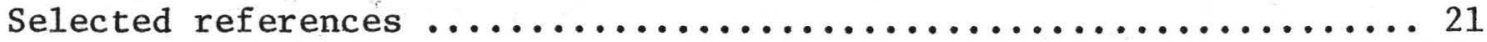

\section{ILLUSTRATIONS}

Page

Figure 1. Map showing location of Pithlachascotee River study

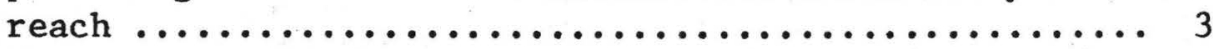

2. Map showing Pithlachascotee River study reach and approximate cross-section locations ............. 5

3. Graph showing areal flood-frequency relations for the

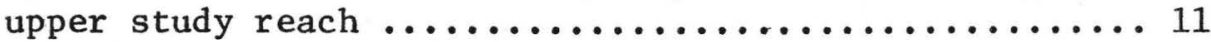

4. Graph showing Crews Lake (South) stage-frequency relation and computed flood heights for cross section 78 .. 18

5. Graph showing Pithlachascotee River profiles for the 2.33-, 5-, 10-, 100-, and 500-year floods .......... 19

TABLES

Table 1. Streamflow and lake-stage records used ............ 8

2. Pithlachascotee River stage-discharge data used ....... 9

3. Pithlachascotee River areal flood discharges used in

flood-height computations ........................ 13

4. Computed flood heights for selected recurrence intervals at 38 cross sections on Pithlachascotee River ........ 14 


\section{CONVERSION FACTORS}

For use of those readers who may prefer to use metric units rather than U.S. inch-pound units, the conversion factors for the terms used in this report are listed below:

U.S. inch-pound units

$$
\begin{aligned}
& \mathrm{ft}^{3} / \mathrm{s} \text { (cubic foot per } \\
& \text { second) }
\end{aligned}
$$

ft (foot)

mi (mile)

$\mathrm{mi}^{2}$ (square mile)

$\mathrm{ft} / \mathrm{mi}$ (foot per mile)

in (inch)
Multiply by

0.02832

0.3048

1.609

2. 590

0.1894

25.40
Metric units

$\mathrm{m}^{3} / \mathrm{s}$ (cubic meter per second)

m (meter)

km (kilometer)

$\mathrm{km}^{2}$ (square kilometer)

$\mathrm{m} / \mathrm{km}$ (meter per

kilometer)

mm (millimeter)

\section{GLOSSARY}

Some of the technical terms frequent1y used in this report are defined in this section. See Dalrymple (1960) and Langbein and Iseri (1960) for additional information regarding flood-frequency analysis and associated terminology.

Correlation coefficient expresses degree of relationship between variables used in regression analyses. A value of 1.0 indicates perfect positive correlation, and a value of -1.0 indicates perfect negative correlation. A value of 0.0 indicates no correlation.

Flood-frequency curve is a graph showing flood magnitudes that will, on the average, be exceeded once within a specified number of years. The Geological Survey uses the log-Pearson Type III distribution for floodfrequency analyses. The distribution is described by the Water Resources Council (1976).

Flood height is water-surface elevation above a selected datum. Mean sea level datum of 1929 is used in this study.

Flood profiles, as provided in this report, are graphs of flood heights (crests) versus distance, measured in the upstream direction. Profiles show crests for flood-peak discharges of specified recurrence intervals along the stream reach. 
Manning's roughness coefficient, $\underline{n}$, is a factor used with open-channel flow equations and is a measure of channel boundary roughness. Typical values of roughness are tabulated for various boundary conditions in a variety of open-channel hydraulic texts. Roughness coefficients are estimated from aerial photographs, available streamflow records, and field site surveys.

Multiple regression analysis refers to determination of regional flood relations expressing flood-peak discharges for 2-, 2.33-, 5-, 10-, 25-, 50-, 100-, 200-, and 500-year recurrence intervals as a function of selected basin parameters, including drainage area, basin length and slope, and percent of basin as lakes and swamps. Regression equations, multiple correlation coefficients, and standard errors of estimate are obtained as part of the analyses. Multiple and simple regression analyses are described by Bryant (1960) and Davies (1961).

Recurrence interval, as applied to flood events such as flood-peak discharges, is the average time interval within which a flood of specified magnitude is expected to be exceeded at least once.

Runoff is that part of precipitation that appears in surface streams. In this report, runoff implies inches per square mile. It is indicated as inches.

Stage-discharge rating is a relation describing discharge as a function of stream stage. Stage-discharge ratings are empirical relations and are normally developed from field measurement of discharge and stage. Approximate stage-discharge ratings are calculated using empirical openchannel flow equations and known channel geometry.

Standard error of estimate expresses reliability of the statistical relation between variables of a regression equation. Standard errors of estimate are given as average percent values and represent the average range that includes about 68 percent of all data used in defining the regression. 

FLOOD PROFILES OF THE PITHLACHASCOTEE RIVER, WEST-CENTRAL FLORIDA

By J. F. Turner, Jr., W. R. Murphy, Jr., and C. V. Reeter

\begin{abstract}
Data defining the magnitude and frequency of flooding are provided for a non-tidal 16-mile reach of the Pithlachascotee River. These data include areal flood-frequency relations and flood heights for the 2-, $2.33-, 5-, 10-, 25-, 50-, 100-, 200-$, and 500-year recurrence intervals. Flood profiles are provided for the 2.33-, 5-, 10-, 100-, and 500-year recurrence intervals.

Study results indicate that flood discharges in the study area are highly variable and are one-third to one-half of regional estimates. Differences between study area and regional estimates are due to large quantities of flood-water drainage to the regional aquifer system in the upper basin, a large karst area of about 138 square miles. Graded roads and bridges located at three sites along the upper study reach will be inundated by various frequency floods.
\end{abstract}

Flood inundation maps can be prepared from flood data presented in this report. 


\section{INTRODUCTION}

The Pithlachascotee River basin is undergoing urban and agricultural development. Urban residential developments are increasing on low-lying waterfront property and coastal areas of the lower Pithlachascotee River basin. Agricultural developments in low-lying inland areas are subject to frequent and severe flooding from tropical storms and hurricanes because of poor surface drainage. For example, a severe storm in 1960 caused extensive areal flooding and damage to developments in low-1ying areas, particularly in the Squirrel Prairie-Masaryktown area (fig. 1).

Flood-control measures for the area include an existing drainage channel (improved) between the Squirrel. Prairie area and Crews Lake (fig. 1) and proposed conversion of the Squirrel Prairie area to a flood-detention area by construction of: (1) dikes across the south end of the Squirrel Prairie area; and (2) a diversion canal to Cypress Creek, a principal tributary to the Hillsborough River (fig. 1). Proposed flood-control measures in the Squirrel Prairie area are not evaluated in this study.

Flood-prone area information is needed for evaluation and regulation of future development in the Pithlachascotee River basin.

\section{DESCRIPTION OF THE BASIN}

The Pithlachascotee River basin, with drainage area of about $195 \mathrm{mi}^{2}$, is located in parts of Hernando and Pasco Counties in west-central Florida. The basin is bounded by the Gulf of Mexico to the west, Cypress Creek to the east, and Anclote River to the south (fig. 1). The Pithlachascotee River originates at Crews Lake near Fivay Junction and flows southwest through Pasco County to the Gulf of Mexico at New Port Richey. Jumping Gully and Fivemile Creek are the principal tributaries to Crews Lake and to Pithlachascotee River, respectively.

The Pithlachascotee River basin is generally rural and is characterized by sand-covered flatlands and eroded ridges. The flatlands consist mainly of lakes, cypress swamps, and surface depressions with numerous sinkholes. Squirrel Prairie is a large depression in the upper basin near Masaryktown, just south of Brooksville (fig. 1).

For purposes of this report, the Pithlachascotee River basin is divided into three parts, referred to as upper, middle, and lower basins. The upper basin extends downstream from the basin boundary to Crews Lake outlet; the middle part, or basin, extends downstream from Crews Lake outlet to Fivemile Creek; and the lower basin, from Fivemile Creek to the Gulf of Mexico. 


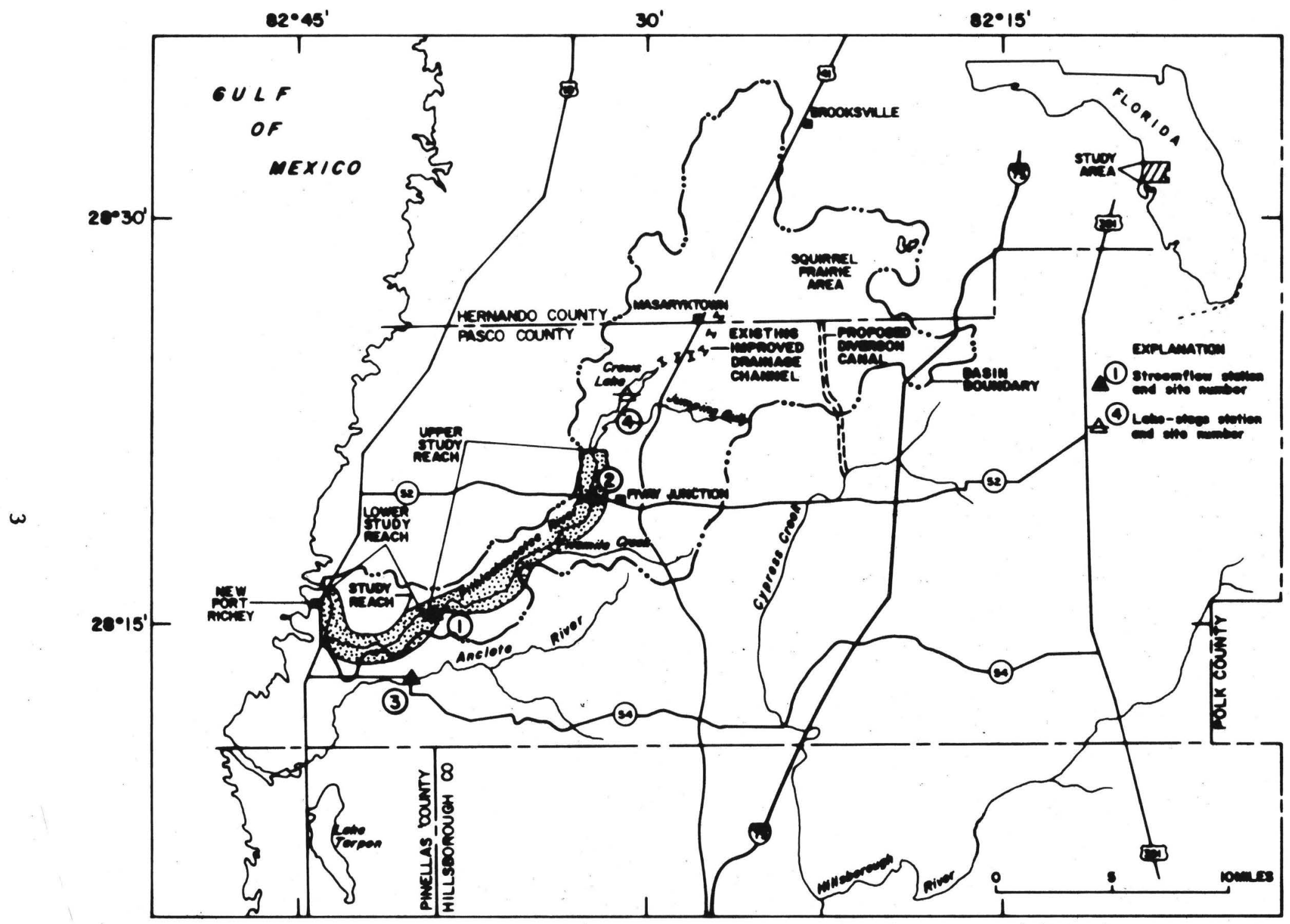

Figure 1.--Location of Pithlachascotee River study reach. 
The upper basin, of about $138 \mathrm{mi}^{2}$, is a large karst area which includes about 71 percent of total basin area. The area has many sinkholes and is believed to be a principal source of recharge to the underlying, regional aquifer system. Stream channels are virtually non-existant on topographic maps covering the upper basin. Numerous lakes in the upper basin are interconnected by small surface channels. None, except Crews Lake, have direct connection to the Pithlachascotee River. Several 1akes, including Crews Lake, are directly connected to the regional aquifer system. According to Cherry and others (1970), a considerable amount of water drains from Crews Lake to the ground-water system. At flood stage, Crews Lake has been observed to rapidly drain through a large sinkhole in the north part of the lake. Water also drains through sinkholes in the Squirrel Prairie area. Because of this drainage, the quantity of water that finds its way downstream in the Pithlachascotee River during storms is much less than would be otherwise expected.

Average annual rainfall for the basin is about $55 \mathrm{in}$, most of which falls June through September. Since 1963, mean annual runoff for the Pithlachascotee River basin (measured at the New Port Richey streamflow station, site 1, fig. 1) has been less than 3 in. In contrast, the annual runoff from most stream basins in west-central Florida is between 10 and 15 in per year.

That part of the basin studied during this investigation extends upstream from U.S. Highway 19 at New Port Richey to Crews Lake (fig. 1). The study reach consists of an upper part and a lower part. The lower study reach extends upstream from U.S. Highway 19 about $6 \mathrm{mi}$ to cross section 22 ( $f i g .2$ ) and is affected by tide. The upper study reach extends about $16 \mathrm{mi}$ upstream from cross section 22 to Crews Lake (fig. 2). Within the upper study reach, the river crosses numerous swamps and appears intermittent on Geological Survey topographic maps. The flood plain varies in width from several hundred feet to $0.5 \mathrm{mi}$ and the stream bed slope averages about $3.5 \mathrm{ft} / \mathrm{mi}$.

Large flood-flow variations occur along the upper study reach. For example, during June 1974, as much as 17 in of rainfall fell on coastal areas of west-central Florida, including the Pithlachascotee River basin. of this amount, about 13 in occurred in a 5-day period during the latter part of June. Annual maximum flows were observed at three points along the upper study reach including Crews Lake outlet (cross section 78, fig. 2 ) and two streamflow stations (sites 1 and 2 , fig. 2). A comparison of these data indicate that flood runoff (per $\mathrm{mi}^{2}$ ) near the downstream end of the upper study reach amounted to more than 10 times that near Crews Lake outlet.

\section{COOPERATION}

Flood-prone area information is needed by local governments to facilitate flood-plain management in the basin. Southwest Florida Water 


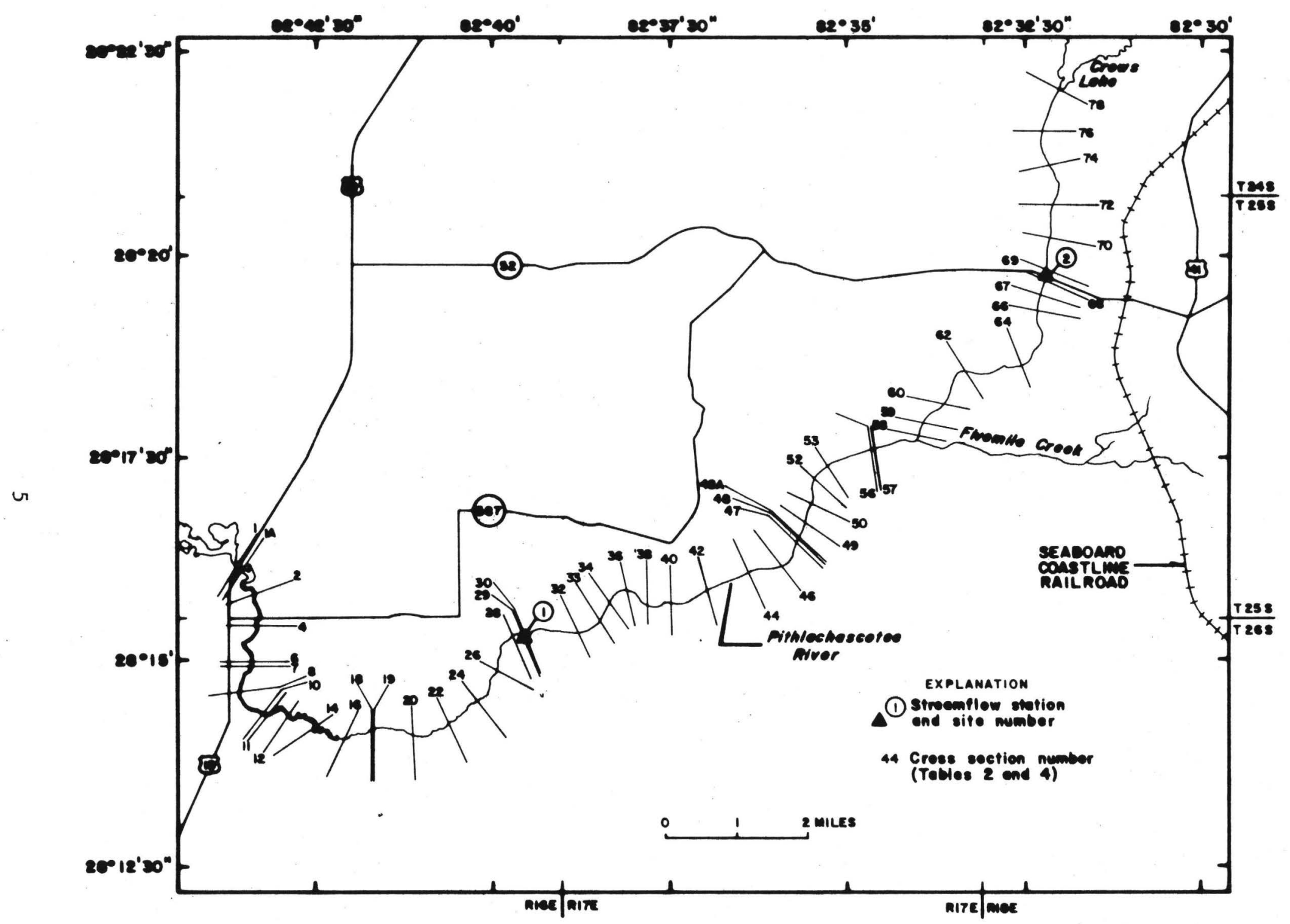

Figure 2.--Pithlachascotee River study reach and approximate cross-section locations. 
Management District has long recognized the need for flood-plain management information, and in 1973 entered into a cooperative progxam with the U.S. Geological Survey to define probable flood levels along principal streams in west-central Florida, including Pithlachascotee River.

Southwest Florida Water Management District provided land-surface elevation data for 53 stream cross sections and photo-base topographic maps used in the study. They also provided information concerning maximum outflow from Crews Lake for the latter part of June 1974.

\section{PURPOSE AND SCOPE}

The purpose of this report is to provide information concerning the magnitude and frequency of flooding for the upper study reach (upstream from cross section 22 to Crews Lake, fig. 2). Flood data provided include flood heights and profiles of selected recurrence intervals. Flood heights were computed in hydraulic analyses using topographic and streamflow data. The approximate upstream limit of significant tidal influence on basin flooding is estimated as part of the study, however, the magnitude and frequency of flooding in the tidally affected lower study reach is not determined.

Flood data provided in this report apply only to current basin conditions. As the waterfront areas continue to develop and flood-control measures now proposed are implemented, flooding potential may change. Under these conditions, information presented in this report may not be completely applicable.

\section{METHODOLOGY}

Flood heights and profiles presented in this report represent crests of floods of selected recurrence intervals along the non-tide affected study reach. Flood heights were computed for 38 channel cross sections located along that part of the study reach not affected by tides. Computed flood heights were plotted on a graph versus measured distance of stream-channel cross section above stream mouth. Flood heights having the same recurrence interval were connected to define profiles.

Flood heights used in constructing the profiles were calculated in a step-backwater analysis using flood-peak discharges for selected recurrence intervals. The Geological Survey step-backwater computer program used (Shearman, 1976) is similar to a procedure described by Chow (1959) and Posey (1950). That procedure requires a beginning flood-peak discharge and corresponding flood stage. Using these data, a velocity head is calculated for the initial downstream cross section and a water-surface elevation (flood height) is assumed at the next upstream cross section. 
Head losses due to friction between these two cross sections are calculated and an energy balance is computed. When the energy balance falls outside selected tolerance limits, the upstream flood height is adjusted, and energy calculation and balance tests are repeated until an acceptable balance is achieved. This procedure is repeated for remaining channel cross-section pairs, beginning at the next cross section upstream and proceeding to the cross section at the upstream end of the study reach.

Step-backwater computations were verified by use of stage-discharge ratings (as extended logarithmically) for the two streamflow stations along the study reach. Data available for these stations are summarized in table 1. The New Port Richey station, located near the beginning of the upper study reach (site 1, fig. 1), has 13 years of record; the Fivay Junction station (site 2, fig. 1), near the upstream end of the upper study reach, has 7 years of record. The stage-discharge data used in the study are summarized in table 2 .

Flood-peak discharges used in the step-backwater analyses were taken from areal flood-frequency relations developed for the upper study reach. These relations are discussed in the following section of this report.

\section{AREAL FLOOD-FREQUENCY RELATIONS}

Short-term streamflow records available for the Pithlachascotee River study reach provide little historical flooding information. Although the flow characteristics of the river are believed to differ in important respects from those of nearby streams because of the large quantity of water that drains to the regional ground-water system at Crews Lake and Squirre1 Prairie (fig. 1), regional flood-frequency data from two sources were evaluated for possible use in the study. These regional sources include Barnes and Golden (1966) and results of a multiple-linear regression analysis of long-term records for 20 streamflow stations in west-central Florida (Murphy, 1977). Regiona1 flood data from Barnes and Golden. (1966) exceed station data for the Pithlachascotee River near New Port Richey by 200 percent. Similarly, regional flood data from the multiple-linear regression analysis were as much as 300 percent greater than station data for Pithlachascotee near New Port Richey. Based on these comparisons, the data from Barnes and Golden (1966) and from the multiple-1inear regression analysis were not used in the study.

Areal flood-frequency relations used are based on Pithlachascotee River streamflow records and include flood-frequency distributions determined for the New Port Richey station (site 1, fig. 2), the Fivay Junction station (site 2, fig. 2), and estimated flood-frequency data for a third site located mid-way between the Fivay Junction station and Crews Lake (cross section 74, fig. 2). Drainage area for cross section 74 is 145 $\mathrm{mi}^{2}$. 
Table 1.--Streamflow and lake-stage records used

\begin{tabular}{|c|c|c|c|c|}
\hline $\begin{array}{l}{ }^{a} \text { Site } \\
\text { number }\end{array}$ & $\begin{array}{l}\text { Streamflow } \\
\text { lake station }\end{array}$ & $\begin{array}{c}\text { Drainage } \\
\text { area } \\
\left(\mathrm{mi}^{2}\right)\end{array}$ & $\begin{array}{l}\text { Period of } \\
\text { record }\end{array}$ & $\begin{array}{c}\text { Records } \\
\text { available }\end{array}$ \\
\hline 1 & $\begin{array}{l}\text { Pithlachascotee } \\
\text { River near New } \\
\text { Port Richey. }\end{array}$ & 182 & $1964-76$ & $\begin{array}{l}\text { Daily stream } \\
\text { stage and dis- } \\
\text { charge. }\end{array}$ \\
\hline 2 & $\begin{array}{l}\text { Pithlachascotee } \\
\text { River near Fivay } \\
\text { Junction. }\end{array}$ & 150 & $\begin{array}{l}1964-66 \\
1973-76\end{array}$ & $\begin{array}{l}\text { Stream stage } \\
\text { (intermittant) } \\
\text { and misc. dis- } \\
\text { charge measure- } \\
\text { ments. }\end{array}$ \\
\hline 3 & $\begin{array}{l}\text { Anclote River } \\
\text { near Elfers. }\end{array}$ & 72.5 & $1946-76$ & $\begin{array}{l}\text { Daily stream } \\
\text { stage and dis- } \\
\text { charge. }\end{array}$ \\
\hline 4 & $\begin{array}{l}\text { Crews Lake } \\
\text { (South) near } \\
\text { Loyce. }\end{array}$ & 138 & $\begin{array}{l}\text { Mar. 1964- } \\
\text { Feb. 1965, } \\
\text { Mar. 1965- } \\
\text { June } 1974\end{array}$ & $\begin{array}{l}\text { Lake stage } \\
\text { (incomplete); } \\
\text { Lake stage } \\
\text { (fragmentary). }\end{array}$ \\
\hline
\end{tabular}

${ }^{a}$ Site number refers to gage locations shown in figure 1. 
Table 2.--Pithlachascotee River stage-discharge data used

\begin{tabular}{|c|c|c|c|c|}
\hline \multirow{2}{*}{$\begin{array}{c}\text { Recurrence } \\
\text { interval, in } \\
\text { years }\end{array}$} & \multicolumn{2}{|c|}{$a_{\text {New }}$ Port Richey } & \multicolumn{2}{|c|}{$\mathrm{b}_{\text {Fivay }}$ Junction } \\
\hline & $\begin{array}{c}\text { Stage, in } \\
\text { feet above } \\
\text { mean sea level }\end{array}$ & $\begin{array}{l}\text { Discharge, } \\
\text { in cubic feet } \\
\text { per second }\end{array}$ & $\begin{array}{c}\text { Stage, in } \\
\text { feet above } \\
\text { mean sea level }\end{array}$ & $\begin{array}{l}\text { Discharge, } \\
\text { in cubic feet } \\
\text { per second }\end{array}$ \\
\hline 2 & 16.8 & 405 & 52.8 & 94 \\
\hline 2.33 & 17.0 & 455 & 53.0 & 115 \\
\hline 5 & 17.9 & 760 & 53.7 & 210 \\
\hline 10 & 18.5 & 1,060 & $c_{54.2}$ & 315 \\
\hline 25 & $c_{19.2}$ & 1,520 & $c_{54.8}$ & 500 \\
\hline 50 & $c_{19.6}$ & 1,900 & $c_{55.0}$ & 660 \\
\hline 100 & $c_{19.9}$ & 2,300 & $c_{55.3}$ & 820 \\
\hline 200 & $c_{20.3}$ & 2,800 & $c_{55.5}$ & 1,050 \\
\hline 500 & $c_{20.7}$ & 3,500 & $c_{55.8}$ & 1,350 \\
\hline
\end{tabular}

a Site 1 , figures 1 and 2 , cross section 29.

Site 2, figures 1 and 2 , cross section 68 .

${ }^{\mathrm{C}}$ lood stages from logarithmically extended stage-discharge ratings. 
Station flood-frequency distributions were determined according to Water Resources Council (1976) guidelines. Because the number of years of streamflow records is short, log-Pearson Type III distributions determined are based on a generalized map distribution skew of -0.05 and correlated flood statistics, including mean and standard deviation. The correlation procedure is referred to in U.S. Water Resources Council (1976) as the "two-station method."

Correlated flood statistics were estimated from the relations based on observed annual flood-peak discharges for the Pithlachascotee River streamflow stations and the Anclote River near Elfers streamflow station (site 3, fig. 1). The New Port Richey relation is based on 13 annual flood-peak discharges and has a correlation coefficient of 0.94 and an average standard error of estimate of 28 percent. The Fivay Junction relation is based on 7 annual flood-peak discharges and has a correlation coefficient of 0.80 and an average standard error of estimate of 59 percent.

Large flood-flow variations occur between Crews Lake and the Fivay Junction station. Therefore, flood discharges for cross section 74, that provide an acceptable match of stream and lake flood heights at Crews Lake outlet (cross section 78, fig. 2), were used in defining areal floodfrequency relations.

Areal flood-frequency relations were developed for the study reach by plotting a semi-logarithmic graph of flood-peak discharges for selected recurrence intervals for each station and cross section 74 versus drainage area. Plotted points were connected with curved lines to form areal relations for each recurrence interval. Areal variation of flood-peak discharge versus drainage area for selected recurrence intervals is shown in figure 3 .

The reliability of the flood-peak discharges for the Pithlachascotee River, as portrayed in figure 3, is difficult to evaluate because of short streamflow records and limited knowledge of basin hydrology. However, the relations shown are believed to be the most reliable that can be developed from the streamflow records available.

\section{FLOOD-HEIGHT COMPUTATION}

Flood heights, having 2-, 2.33-, 5-, 10-, 25-, 50-, 100-, 200-, and 500-year recurrence intervals, were computed for the upper study reach in a step-backwater analysis. Hydraulic data used in the analysis include: land-surface elevations for 38 stream-channel cross sections, values of Manning's roughness coefficient, and stage-discharge ratings for the New Port Richey and Fivay Junction streamflow stations. These ratings are listed in table 2 . 


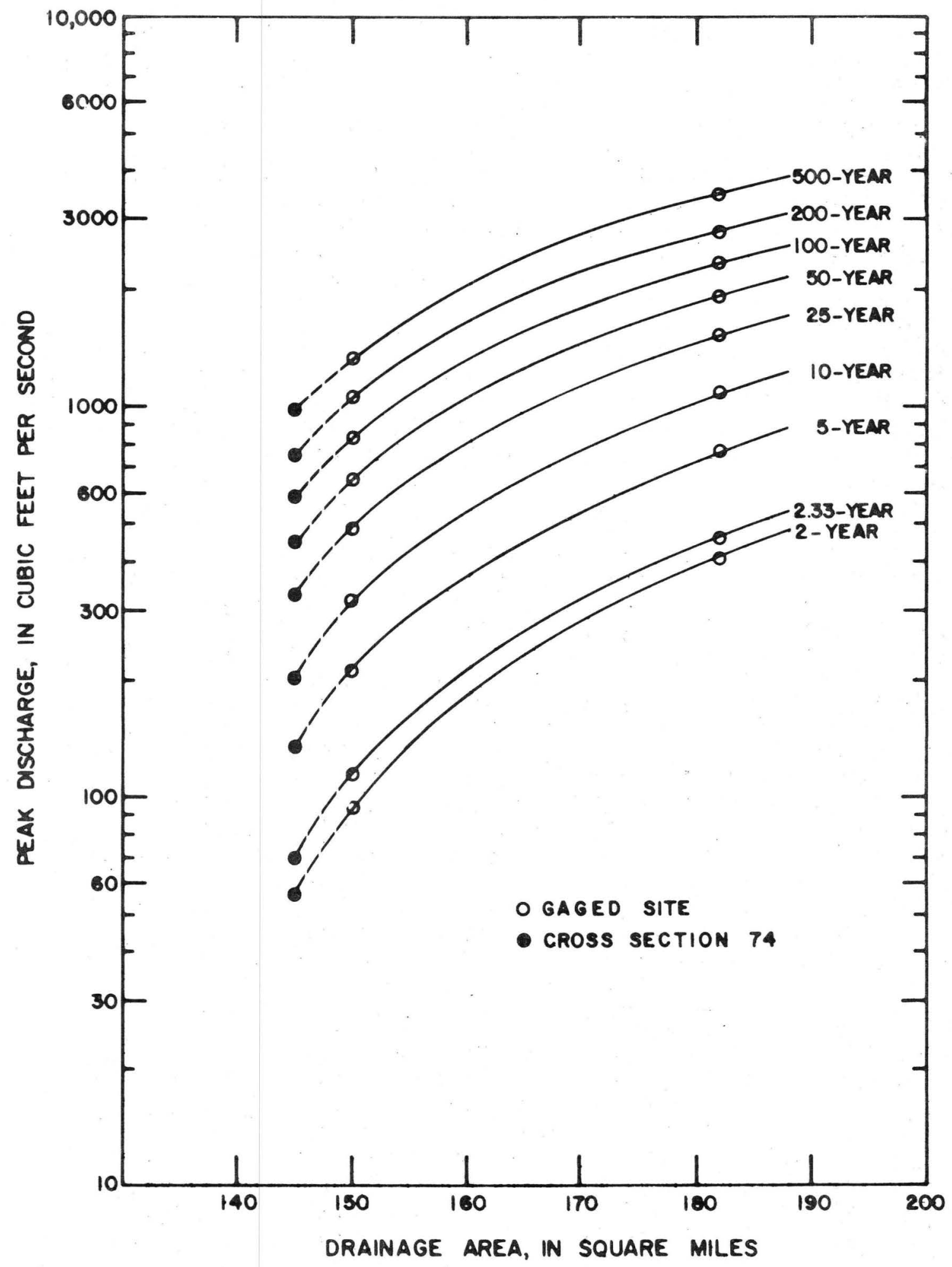

Figure 3.--Areal flood-frequency relations for the upper study reach. 
Stream-channel cross sections are defined by horizontal distance and land-surface elevation coordinates. A sufficient number of land-surface elevations were obtained so that connecting adjacent coordinate points with straight lines adequately describes the stream channel and flood plain cross-section geometry.

Cross-section data were scaled from $1: 2,400$ and $1: 4,800$ photobase topographic maps, having 1 - and 2 -ft contour intervals, respectively. Bridge-section and low-water channel data were obtained in field surveys. Special effort was made at bridge sections to consider wingwall, abutment configuration, and angle between the bridge alinement and the main thread of the stream.

Cross sections are numbered in approximate sequence upstream beginning with 1 at U.S. Highway 19 at New Port Richey and ending with 78 at Crews Lake. Cross-section locations are shown in figure 2. The distances of the cross sections upstream from the mouth, listed in table 4, were measured along the low-water channel. However, because the low-water channel for much of the study reach is not clearly identified on maps, the position was estimated. Therefore, cross-section locations shown on figure 2 are approximate.

Roughness coefficients are a measure of resistance to flow at and between cross sections. Values of roughness coefficient used were selected on the basis of photobase maps, streamflow measurements, and field surveys. Roughness values were adjusted so that computed flood heights agreed with stage-discharge rating curves (as extended logarithmically) for the New Port Richey (site 1, fig. 2) and Fivay Junction (site 2, fig. 2) stations.

Flood heights were computed for all cross sections shown in figure 2 using data described above. Beginning flood elevations for cross section 1 were taken from an approximate stage-discharge rating determined by use of Manning's open-channel flow equation (Chow, 1959) neglecting affects of tide. Flood-peak discharges used in the analysis for the upper study reach were taken from areal flood-frequency relations shown in figure 3 , and are listed in table 3. Flood-peak discharges for the lower study reach were estimated by extending areal flood relations, shown in figure 3 , to a drainage area of $195 \mathrm{mi}^{2}$. Reduced flood-peak discharges were introduced into the step-backwater analysis to compensate for drainage area decreases of 3 to 10 percent.

Because of data limitations, and because the upstream extent of the tide affected reach depends primarily on tide conditions in the Gulf of Mexico, a precise determination of the upstream limit of tidal flooding was not attempted in this investigation. The approximate upstream limit of significant tidal flooding is arbitrarily taken as the intersection of the horizontal projection of the 100-year tide height (about $14 \mathrm{ft}$ above mean sea leve1) (figure 5A, Ho and Tracey, 1975) with the 100-year fluvial flood height. This intersection is located between cross sections 22 and 24 (fig. 2). Therefore, computed flood heights for cross sections 1 through 20 are assumed to be affected by tide and are not listed in table 4 . 
Table 3.--Pithlachascotee River areal flood discharges used in flood-height computations

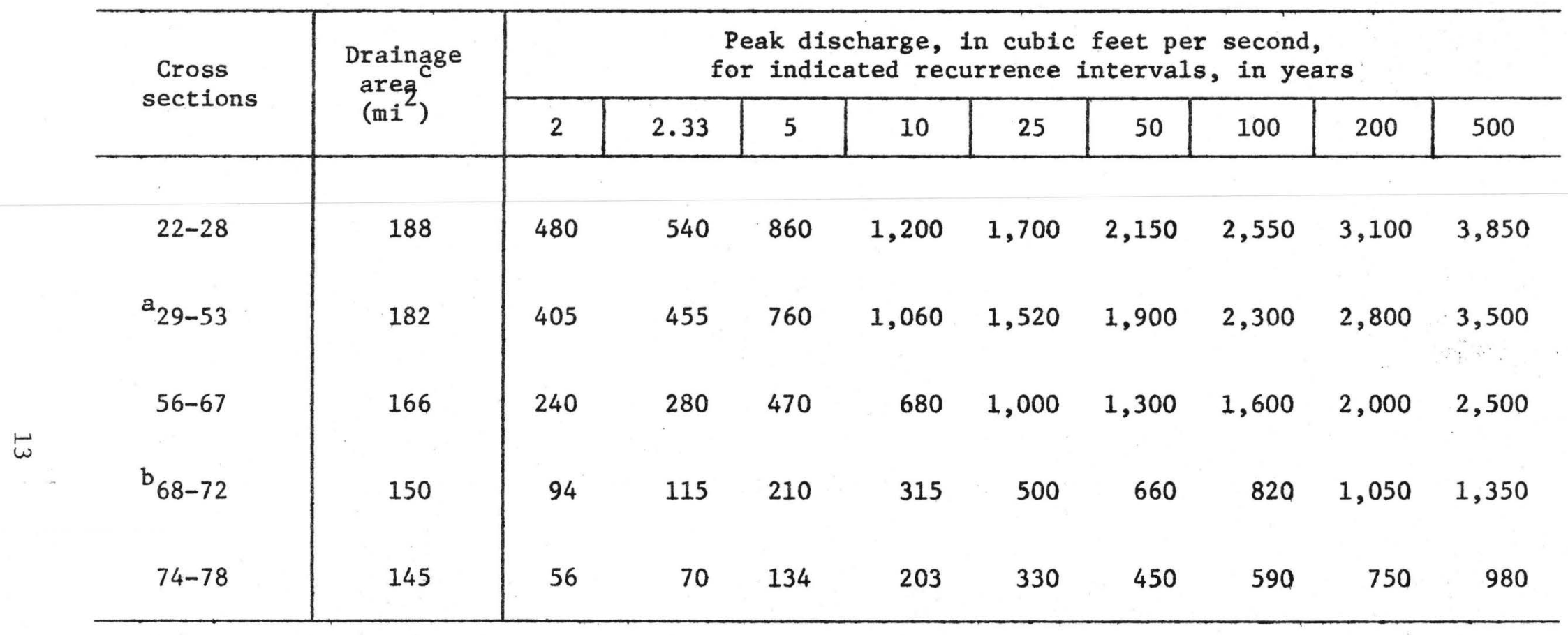

a Site 1, figures 1 and 2, New Port Richey streamflow station.

bite 2, figures 1 and 2, Fivay Junction streamflow station.

Drainage area values used in determining flood-peak discharges from areal flood-frequency relations shown in figure 3. 
Table 4.--Computed flood heights for selected recurrence intervals at 38 cross sections on Pithlachascotee River

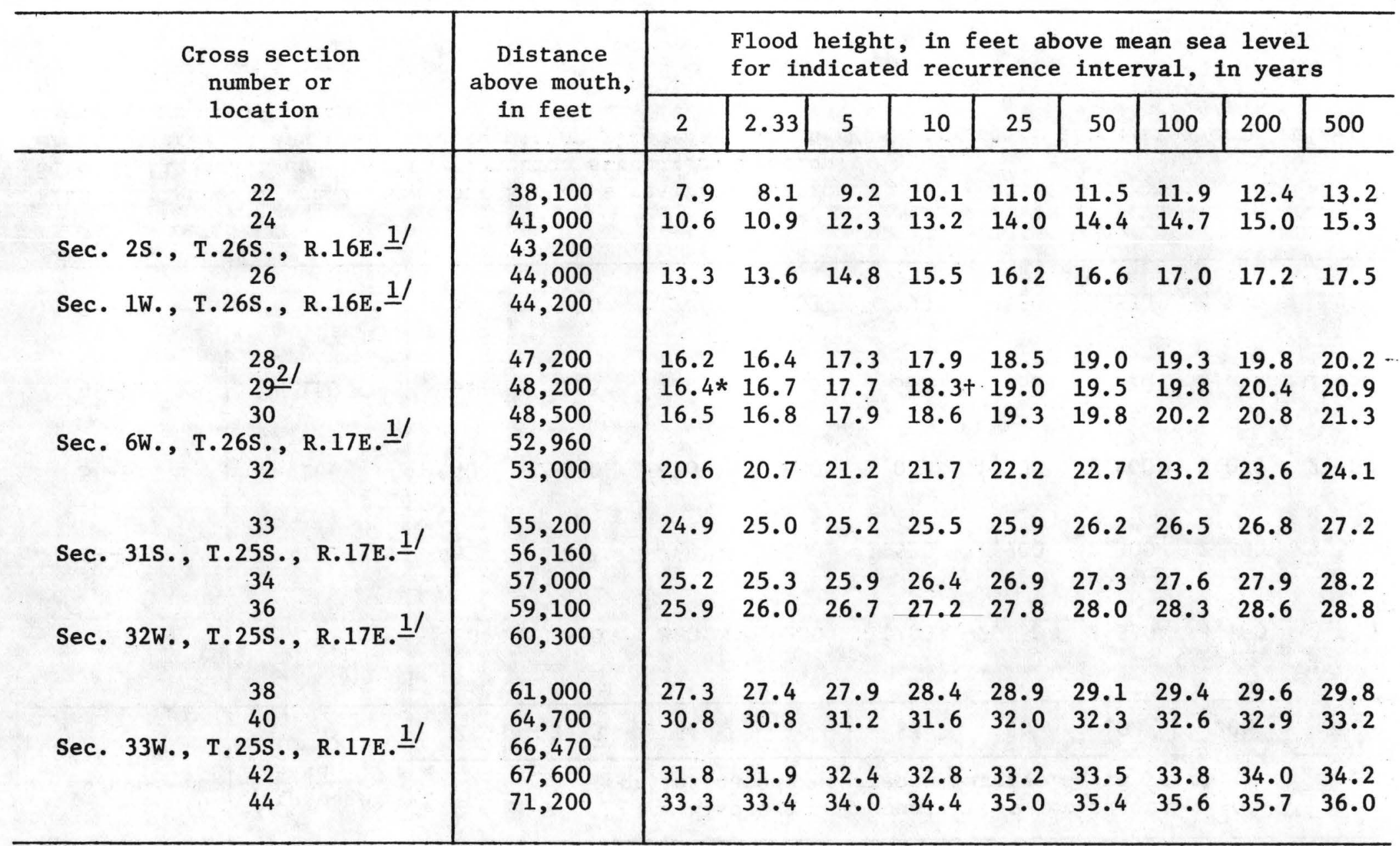

Footnotes appear at end of table. 
Table 4.--Computed flood heights for selected recurrence intervals at 38 cross sections on Pithlachascotee River - continued

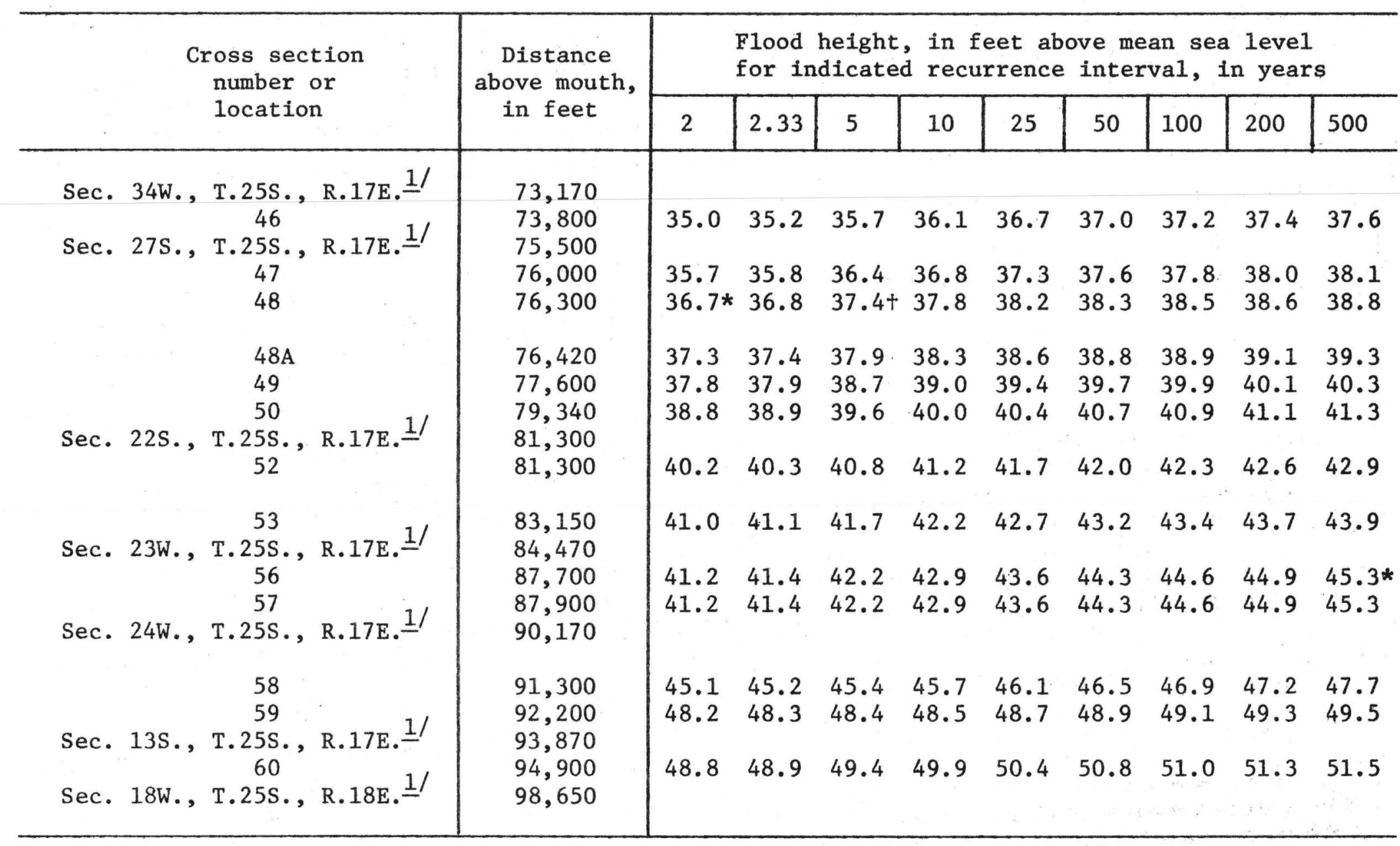


Table 4.--Computed flood heights for selected recurrence intervals at 38 cross sections on Pithlachascotee River - continued

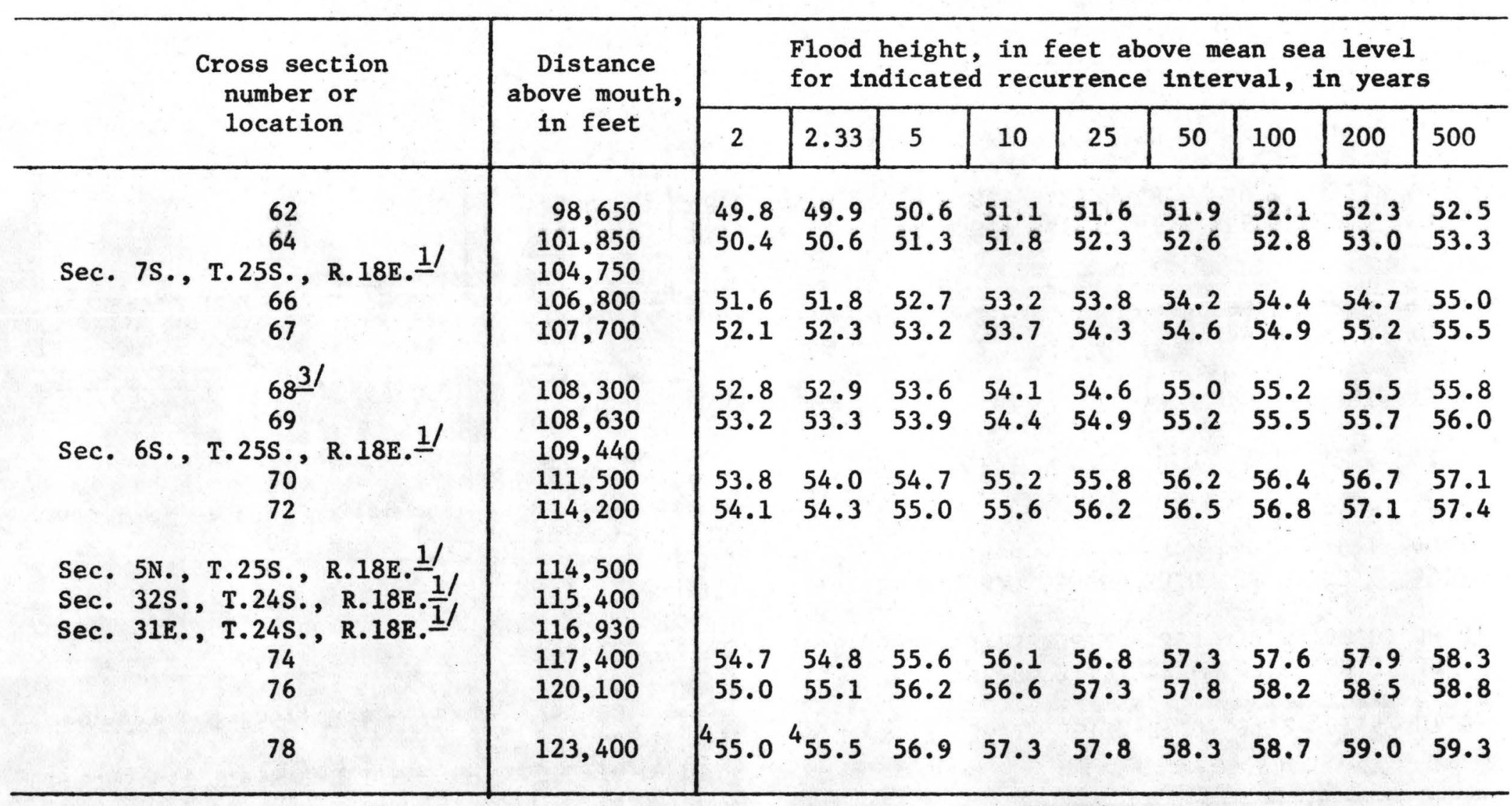

1/ Section line of indicated township and range that intersects Pithlachascotee River.

2/ Pithlachascotee River near New Port Richey stream gaging station (site 1, fig. 1).

3/ Pithlachascotee River near Fivay Junction stream gaging station (site $2, \mathrm{fig} .1$ ).

4/ Flood heights for 2- and 2.33-year recurrence intervals for cross section 78 from Crews Lake stage-frequency relation ( $\mathrm{fig}$. 4).

* Road inundated at this and higher floods.

+ Bridge inundated at this and higher floods. 
Flood heights computed in step-backwater analyses are summarized in table 4 for cross sections 22 through 78. Approximate distances above the mouth are also listed in table 4 for the Pithlachascotee River where crossed by land-section lines. Locations of these lines are shown in figure 5 .

Stage-discharge ratings for New Port Richey and Fivay Junction were extended logarithmically for comparison with computed flood heights at cross sections 29 and 68, respectively. Computed flood hęights in table 4 agree with values from the extended ratings within about $-0.5 \mathrm{ft}$.

An approximate stage-frequency relation was developed for Crews Lake (fig. 4) using one historic peak and ten annual maximum lake stages. Graphical plotting positions used are described by Dalrymple (1960). Except for recurrence intervals of 2 and 2.33 years, computed flood heights for cross section 78 (fig. 2) agree with values from the stage-frequency relation. Because of data 1imitations, the Crews Lake stage-frequency relation is believed to be more reliable than results of the step-backwater analysis for 2- and 2.33-year floods. Therefore, 2- and 2.33-year flood heights shown in table 4 for cross section 78 were taken from the Crews Lake stagefrequency relation (fig. 4).

\section{FLOOD PROFILES}

Flood profiles shown in figure 5 were constructed from flood heights listed in table 4 by plotting the flood height at each cross section and connecting the plotted points with straight. lines for each recurrence interval selected. Flood profiles are shown for recurrence intervals selected because of close profile proximity to each other.

Profiles shown in figure 5 generally parallel the stream bed throughout the upper study reach illustrating uniform flood flow for Pithlachascotee River. Brief irregularities do occur in profiles at three points; however, these occur as a result of channel constriction and road grades.

Flood data shown in figure 5 and listed in table 4 were compared with elevation data for all highway and bridge site crossings in the upper study reach. Results of the comparisons indicate that graded roads and bridges located at cross sections 29,48 , and 56 will be inundated by various frequency floods. Affected sites and recurrence intervals for which inundation occurs are summarized below:

Recurrence interval at which inundation occurs, in years

Cross section

48

56

Road grade

2 and above

2 and above

500 and above
Bridge

10 and above

5 and above 


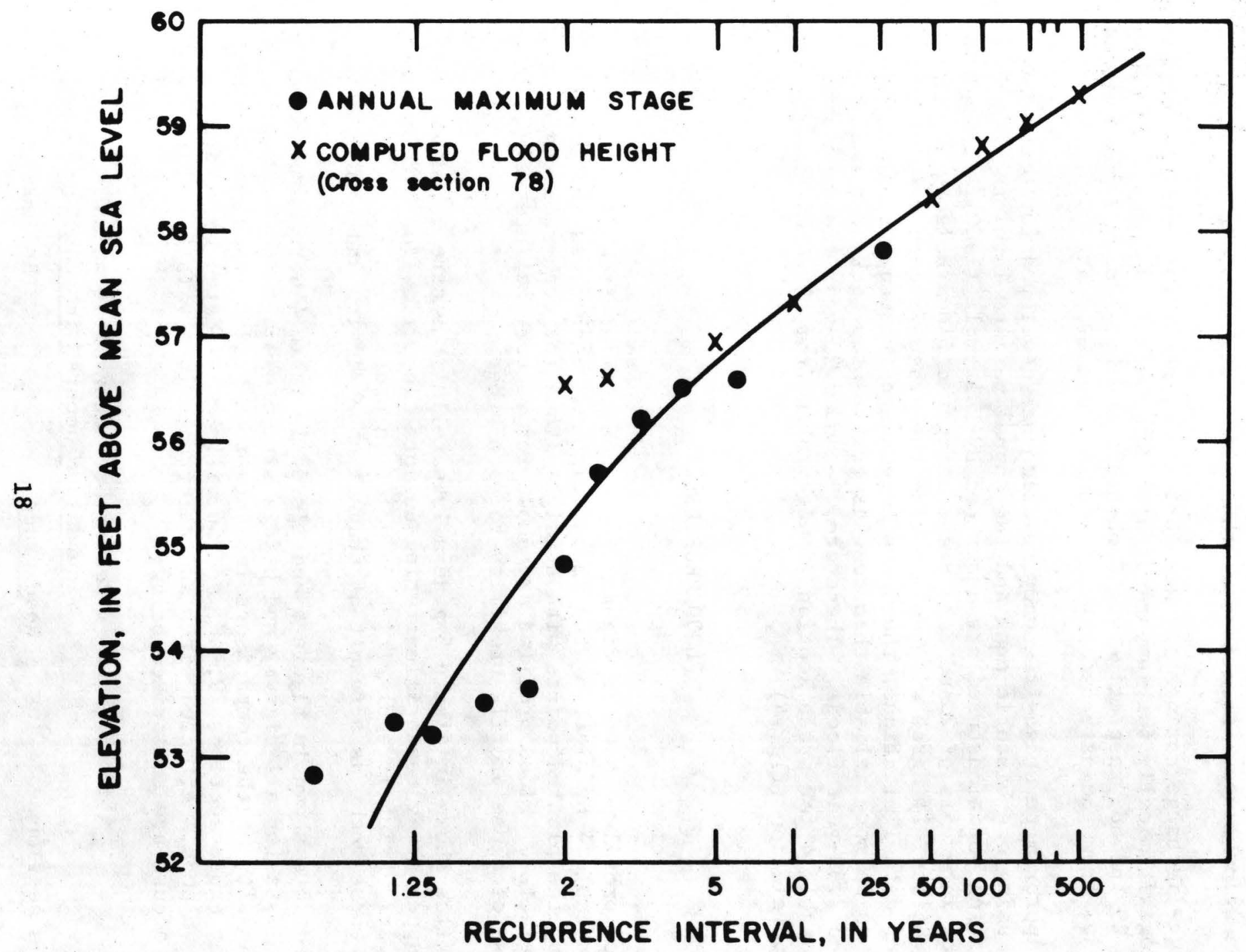

Figure 4.--Crews Lake (South) stage-frequency relation and computed flood heights for cross section 78 . 


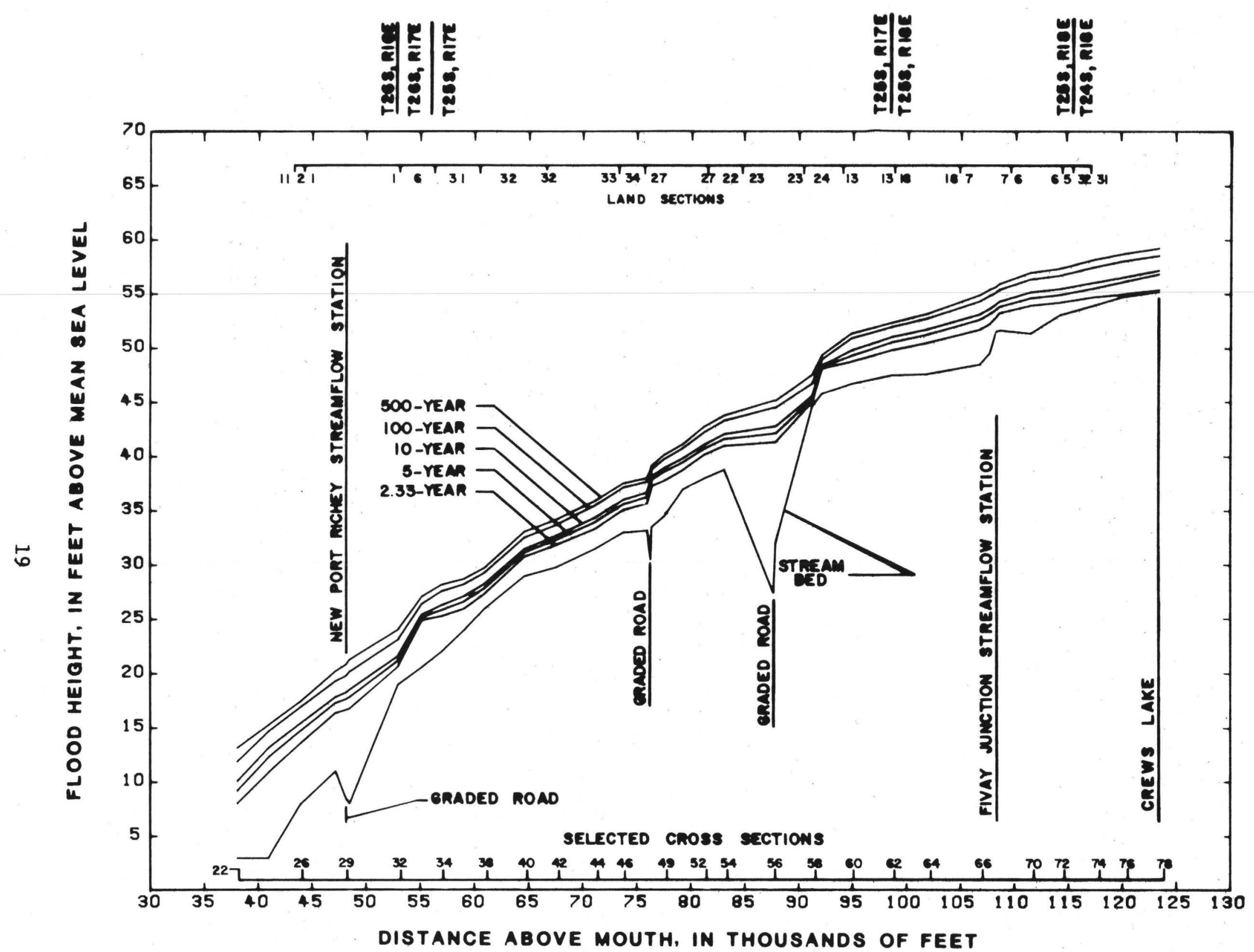

Figure 5.--Pithlachascotee River profiles for the 2.33-, 5-, 10-, 100-, and 500-year floods. 
SUMMARY

The Pithlachascotee River is a coastal stream in west-central Florida that discharges directly into the Gulf of Mexico. The stream drains about $195 \mathrm{mi}^{2}$ of predominantly rural 1and. Urban residential development is increasing near the coast. Low-1ying areas near the Pithlachascotee River main stem are subject to flooding, particularly during large regional storms.

Flood-control measures are proposed for the Pithlachascotee River basin, including construction of a flood-detention area and a diversion canal. However, proposed changes in the basin are not considered in this study.

The upper $138 \mathrm{mi}^{2}$ of the Pithlachascotee River basin is a large karst area, has many sinkholes, and is believed a principal source of recharge to the underlying regional aquifer system. Because of this drainage, the quantity of water that finds its way downstream during storms is much less than would otherwise be expected.

Flood heights having recurrence intervals of $2,2.33,5,10,25,50$, 100,200 , and 500 years were determined for the upper study reach using areal flood-frequency data determined from available flood data for the Pithlachascotee River and for a nearby stream. These data, and profiles for the 2.33-, 5-, 10-, 100-, and 500-year floods are presented. Flood data provided are for nontidal areas of the Pithlachascotee River upstream to Crews Lake, under current basin conditions.

Study results indicate that flood discharges in the study area are highly variable and are one-third to one-half of regional estimates. Differences between study area and regional estimates are due to large quantities of flood water drainage to the regional aquifer system in the upper basin. Graded roads and bridges located at three sites in the upper study reach will be inundated by various frequency floods.

As population and urban development continue to grow in the Pithlachascotee River basin, proposed flood-control measures may be implemented to protect existing development and to provide for orderly future development. As these changes occur, basin hydrology will also undergo modification. Determination of the extent of areal flooding under future basin conditions will require recomputation of flood heights and profiles to reflect changes in area hydrology. 


\section{SELECTED REFERENCES}

Bailey, J. F., and Ray, H. A., 1966, Definition of stage-discharge relation in natural channels by step-backwater analysis: U.S. Geological Survey Water-Supp1y Paper 1869-A, 24 p.

Barnes, H. H., Jr., 1967, Roughness characteristics of natural channels: U.S. Geological Survey Water-Supply Paper 1849, 213 p.

Barnes, H. H., Jr., and Golden, H. G., 1966, Magnitude and frequency of floods in the United States, Part 2-B. South Atlantic Slope and Eastern Gulf of Mexico basins, Ogeechee River to Pear1 River: U.S. Geological Survey Water-Supply Paper 1674, 409 p.

Bryant, Edward C., 1960, Statistical analysis: New York, McGraw Hill, 303 p.

Cherry, R. N., Stewart, J. W., and Mann, J. A., 1970, General hydrology of the middle Gulf area, Florida: Florida Department of Natural Resources, Bureau of Geology Report of Investigation 56, 96 p.

Chow, V. T., 1959, Open-channel hydraulics: New York, McGraw Hil1, sec. 15-32.

Coble, R. W., 1973, The Anclote and Pithlachascotee Rivers, as watersupply sources: Florida Department of Natural Resources, Bureau of Geology Map Series No. 61, 1 p.

Dalrymple, Tate, 1960, Flood-frequency analysis: U.S. Geological Survey Water-Supp1y Paper 1543-A, 80 p.

Davies, Owen L., ed., 1961, Statistical method in research and production (3rd ed.), New York, Hafer, 396 p.

Ho, Francis P., and Tracey, J., 1975, Storm tide frequency analysis for the Gulf coast of Florida from Cape San Blos to St. Petersburg Beach: National Oceanic and Atmospheric Administration, Technical Memo, NWS HYDRO-20, $34 \mathrm{p}$.

Langbein, W. B., and Iseri, K. T., 1960, General introduction and hydrologic definitions: U.S. Geological Survey Water-Supply Paper 1541-A, 29 p.

Linsley, R. K., Kohler, M. A., and Paulhus, J. L. H., 1958, Hydrology for engineers: New York, McGraw Hil1, 689 p.

Murphy, W. R., Jr., 1977, Flood profiles for lower Brooker Creek, westcentral Florida: U.S. Geological Survey Water-Resources Investigations 77-115, $21 \mathrm{p}$.

Posey, C. J., 1950, Gradually varied channel flow, in Rouse, H., ed., Engineering Hydraulics: New York, John Wiley and Sons, p. 625-629.

Pride, R. W., 1962, Floods at Tampa, Florida: U.S. Geological Survey Hydrologic Investigation Atlas HA-66. 
Riggs, H. D., 1968, Frequency curves: U.S. Geological Survey Techniques Water-Resources Investigations, book 4, chap. A2, 15 p.

Shearman, J. O., 1976, Computer program E431 user's manual: U.S. Geological Survey Open-File Report 76-499, 175 p.

U.S. Soil Conservation Service, 1966, Methods of flow-frequency analysis, in Notes on hydrologic activities: U.S. Soil. Conservation Service Bulletin 13, 42 p.

U.S. Water Resources Council, 1976, Guidelines for determining flood flow frequency: U.S. Water Resources Council Bulletin 17, Washington, U.S. Government Printing Office. 